Cahiers de recherches médiévales

\title{
Arthur's Character and Reputation in Yder
}

Norris J. Lacy

\section{(2) OpenEdition}

Journals

Electronic version

URL: https://journals.openedition.org/crm/2650

DOI: $10.4000 / \mathrm{crm} .2650$

ISSN: 1955-2424

\section{Publisher}

Honoré Champion

\section{Printed version}

Date of publication: 15 December 2007

Number of pages: 41-48

ISSN: 1272-9752

\section{Electronic reference}

Norris J. Lacy, "Arthur's Character and Reputation in Yder", Cahiers de recherches médiévales [Online]

14 | 2007, Online since 15 December 2010, connection on 15 December 2022. URL: http:// journals.openedition.org/crm/2650 ; DOI: https://doi.org/10.4000/crm.2650 


\section{rin}

\section{Arthur's Character and Reputation in Yder}

When Arthur is first mentioned in the early thirteenth-century French romance Yder, the young knight Yder has saved the king's life, but without knowing the identity of the person he has rescued. When, the following day, he asks someone who that stranger was, the reply is an entirely traditional and expected encomium :

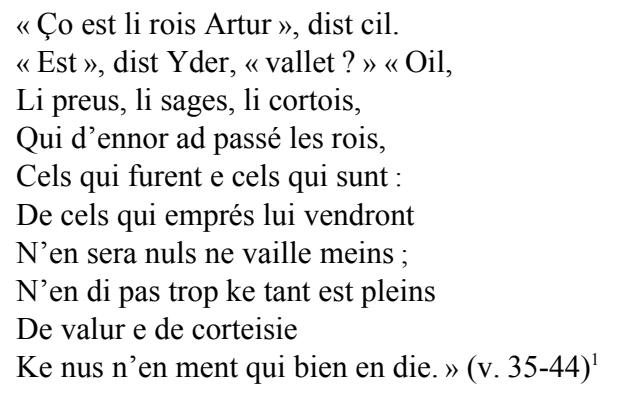

Such praise is a standard Arthurian trope, and there is in principle very little to surprise us about it. Numerous romances go to great lengths to speak of Arthur's greatness, even as many of those same romances set out to dramatize his flaws.

This romance, however, offers a special case, because here Arthur, according to traditional assessments, is not just flawed but genuinely evil. If those views are correct, the praise quoted above should soon begin to ring hollow : it is clearly not the portrait of an evil or despicable man.

Arthur's character in this romance is the central focus of an important 1980 article titled «King Arthur as Villain in the Thirteenth-Century Romance Yder» by Beate Schmolke-Hasselmann, and of a related 1988 article by Alison Adams ${ }^{2}$. Both emphasize Arthur's conspicuous character flaws, identified by Adams as jealousy and especially a lack of loyalty. She characterizes the narratorial depiction of the king as «hostile» (p. 72) and refers to «the unconventional representation of values within which Arthur and his henchman Keu are consistently depicted in the harshest of possible lights [...]» (p. 75). The notion of Arthur as villain is echoed most dramatically by Keith Busby, who writes that Yder is an «anti-Arthur romance » and that $"[\ldots]$ everything that has to do with Arthur and the court [is] evil, and everything non-Arthurian (especially the hero), good. $»^{3}$

\footnotetext{
${ }^{1}$ A. Adams, ed. and trans., The Romance of Yder, Cambridge, Brewer, 1983, p. 29.

${ }^{2}$ The former was published in Reading Medieval Studies, 6, 1980, p. 31-43; the latter, titled "The Roman d'Yder: The Individual and Society », is in The Legacy of Chrétien de Troyes, ed. N.J. Lacy, D. Kelly, and K. Busby, Amsterdam, Rodopi, 1988, vol. 2, p. 71-77.

3 "Yder», in N.J. Lacy, ed., The New Arthurian Encyclopedia, New York, Garland, 1991, p. 529.
}

Cahiers de Recherches Médiévales, 14, 2007 
It is indisputably correct that $Y d e r$ is in some ways an anomalous romance. Most romances, especially in French ${ }^{4}$, show Arthur as a flawed monarch, but scarcely to the extent indicated by the three judgments - and especially Busby's cited here. Although I have no desire to refute those judgments entirely, nor do I believe it could be done, my purpose here is to inject some nuance into the traditional reaction to the Arthur of Yder.

Two episodes in particular appear to sponsor critical condemnations of Arthur. One concerns Arthur's intense jealousy; and jealousy, as the narrator reminds us, is a cruel thing ( Cruele chose a en gelosie», v. 5244). Roughly twothirds through the romance, Yder returns to court after a triumph, and

\author{
Li reis e li barons qui l'ouent \\ En sont joiant e tuit le loent; \\ De lor joie sunt tuit joios \\ Fors solement Keis l'envios. (v. 5129-32).
}

Although Kay's jealousy is emphasized here - and as I shall argue, he will turn out to be the real villain of this romance - the king, along with the barons, reacts in a quite positive manner to Yder's return. This is hardly the portrait of an evil Arthur. However, the very next passage does dramatize his jealousy. The narrator, in one of his frequent interventions (this one twenty-five lines long, v. 5143-67), characterizes jealousy as a «fever of the heart», an incurable attack, an overwhelming passion; he says that a jealous man can never know happiness or have rest; jealousy will destroy him, etc. ${ }^{5}$ These observations are then illustrated dramatically (v. 5185-220), as Arthur asks Guenevere what she would do were she to lose him; she replies that she would die. Although most of us would take this to be a prudent and satisfactory answer, he continues to interrogate her and to modify the form of the question, asking whom she would marry in the event of his death her answer is «no one»- and finally pressing her to indicate whom she would accept if he were dead and she were required to remarry. She replies that if she could not avoid that terrible situation, Yder would perhaps displease her less than others. Having forced such a response, a furious Arthur vows that he will find an opportunity to do harm to Yder - to cause him a «mal trebuc» («ruin» or «downfall», v. 5235). He wants to destroy Yder (v. 5241). He never asserts

${ }^{4}$ Though in French, the romance may reflect English attitudes more than French ones. B. Schmolke-Hasselmann has suggested that the hostile representation of King Arthur may reflect the political situation in England under King John. See Der arthurische Versroman von Chrestien bis Froissart, Tübingen, Niemeyer, 1980, p. 204-05. A. Adams concludes that the romance was written «[...] either in the Western part of France which was subject to the English crown or else, perhaps more probably, by a poet of continental origin living in England during the reign of King John, 1199-1216» (p. 13).

${ }^{5}$ In one of these lines the narrator argues that «Il n'i a tel mal en tot le monde» (v. 5157). Adams translates «mal» as «evil», and although that is certainly not a mistranslation, one wonders if her choice may not have been dictated by the traditional view that Arthur himself is evil. «Mal» can as easily mean «illness», which fits the characterization of jealousy throughout this passage. 
unambiguously - and this is an important fact - that he seeks Yder's death, but it is undeniable that his extreme jealousy and anger are dangerous emotions indicative of profound flaws in the $\mathrm{king}^{6}$.

The second of the passages that seem to convict Arthur occurs when he goes in search of adventure, taking with him Gauvain, Yvain, Yder, and Kei. Yder ventures ahead of the others to fight two giants or monsters; the smaller of the two is fifty feet tall or more, v. 5502-03). The other knights arrive to find him victorious, sitting beside the giants' bodies. Adams's translation informs us that Arthur and Kei would have preferred that he be dead (v. 5671). Specifically, the Old French rendering reads, «Li reis quide qu'il seit grevez / E Keis, mes il fust mort lor voil : / Tost en eussent fait le doel» (v. 5670-72). She translates that as «Arthur thought he [Yder] was wounded, and so did Kei, but they would have liked him to be dead; they would have grieved for him at once «. Here is the romance's most explicit expression of Arthur's jealousy and perhaps of his evil nature. Yet the passage is problematic and, I suspect, corrupt.

Obviously, both editing and translating are at the same time acts of interpretation. In this passage, if we accept the editor's punctuation, we have to concur with Busby's contention about the evil that Arthur incarnates. Yet, punctuated differently (as «mes il fust mort, lor voil tost en eussent fait le doel»), the passage reads : «but if he had been dead [or, literally, "were he dead»], they would have wanted to grieve for him immediately. »

A simple change of the editor's punctuation thus modifies the characterization of Arthur. Still there remains a problem here, because in either case, Arthur's and Kei's views coincide. Thus, if we repunctuate so as to avoid contending that Arthur sought Yder's death, we also have to concede that Kei would grieve for the hero, and that is patently untrue. Nonetheless, that reading appears preferable, for two reasons. First, although Arthur, in his jealous rage, had vowed to rid himself of Yder and thus might well be threatening death, such a threat, as I noted earlier, is not explicit. Thus, the scene with the giants' bodies is the only instance in which, at least as Adams interprets it, Arthur clearly wants Yder dead. Second, and more important, there is strong support for my emended reading in the next scene. There Kei poisons Yder ${ }^{7}$, and Arthur's reactions are telling : he is greatly

\footnotetext{
${ }^{6}$ Soon afterward, Arthur asks Gauvain about Yder but curiously does not mention the latter's name. He first characterizes him as the knight whom the ladies find so attractive, then as the handsome one who wins ladies' hearts. Gauvain does not know whom Arthur is referring to until the king simply calls Yder «the good knight» at which time Gauvain understands the reference. Yder is most clearly identified - other than by Arthur - by his chivalric qualities rather than by amorous reputation. See v. 5260-72. In Adams's translation, Gauvain says of Yder that «[...] in love I know no better than him» (v. 5271-72), but the manuscript reading is not «en amor » but «en demuor» and in her note to that line Adams suggests that another acceptable emendation is "sans demuor", without delay. She considers that her choice better fits the context, but in fact I find the alternative preferable: Gauvain does not recognize the description of Yder as ladies' man, but when he is described as a good knight, Gauvain immediately («sans demuor ») knows who it is.

${ }^{7}$ In her summary of the romance, Adams says that Kei poisons Yder out of hatred but also because he «know[s] Arthur's wishes » (p. 17), but I find no such indication in the text.
} 
«esbahi» (astonished or appalled, 5800); then the king «Le cors a seignié si s'en part ; / Il prie Deu que l'alme en gart / Des mals e des peines d'enfer» (v. 5825-27). These are reactions inconsistent with a desire for Yder's death. In fact, when Yder, healed, returns to court, the king is happy to see him, and from that point on he remains on the best of terms with Arthur («mult bien del rei», v. 6397).

If it is agreed that Arthur is not the entirely evil villain of the romance, then just what are his flaws, beyond irrational jealousy? In fact, the king does not always do the wrong thing, but often he neglects the right thing or does things in the wrong order, by which is meant that he is irresponsible and forgetful and that he rarely has his priorities correctly ordered.

As we noted, Arthur, at the beginning, has been rescued by a young, unknown knight, who happens to be Yder ${ }^{8}$. Learning whom he has saved, Yder hopes to join Arthur's court, but inexplicably, Arthur largely ignores the young man, forgetting to reward him or even to thank him. Yder's anger and disappointment at this affront are exacerbated when Arthur soon makes what appears to be an irresponsible decision. A young woman arrives to say that her lady needs Arthur's assistance, because her castle is besieged by the Black Knight (v. 67ff.). Arthur, who had given the castle to the lady and had sworn to protect her, readily agrees to offer assistance but insists that the task will have to wait. First he must besiege the castle of Rougemont, because its lord, Talac, refuses to accept Arthur as liege lord, and Arthur must remedy that. The messenger berates him, pointing out that his prior duty was to her lady, because Arthur had given his promise to her first. The king, though, insists that he must first besiege Rougemont, arguing stubbornly that «Dist l'ai, si ne m'en veil dedire» (v. 109)9. Yder soon leaves court, distressed to see that Arthur is not doing his duty (v. 129). The narrator does not indicate that either of Arthur's tasks is unworthy or improper, but clearly the king's priorities are disordered.

Before long, Arthur is reminded of Yder and asks that the young man be brought to him. Informed that Yder has left, Arthur announces that he, the king, has shamed himself by forgetting about the young man who saved him. He sends twenty men to seek Yder, promising them rich gifts if they bring him back to court. Just when we have evidence of Arthur's failings, he seeks to redeem himself: he does so too late, of course, but with good intentions. His forgetting Yder, then regretting it and sending men to search for him, suggests that Arthur could be forgetful,

\footnotetext{
${ }^{8}$ The beginning of the romance is lacking in the unique manuscript (Cambridge University Library, Ee.4.26), but retrospective reference to events makes it simple enough to reconstruct the major narrative lines that open the work. Yder's mother's lover had abandoned her, leaving her with half of a ring. Eventually, Yder sets out to find his father. During his travels, he falls in love with Queen Guenloie, but she demands that he earn her love by his exploits. Leaving her, he meets a knight who has become lost while hunting. He serves the man, killing two attackers. Thereupon, the extant text begins. A slightly more detailed summary is offered by Adams, p. 13. The passages in Yder that enable us to make this reconstruction are v. 909ff. and $1754-1832$.

${ }^{9}$ The messenger angrily responds, « Si de cel estes desdisanz, / Li desdiz est de ça plus granz / Ke de premiers diz vos desdites » ( v. 111-13).
} 
distracted, or perhaps even irresponsible - but his actions argue against the contention that he is simply evil.

The text later offers a sequence that reflects and almost duplicates the one in which Arthur had to choose between defending a lady's castle and fighting Talac. Yder's ladylove, Guenloie, decides to besiege Talac's castle; since the latter is now Arthur's vassal, the king will surely - so Guenloie thinks - come to his assistance, and just as surely he will bring Yder with him, enabling her thus to see the man she loves (v. 3399-551). But Arthur refuses to help Talac, or more precisely, he postpones the deed because, he says, he must first go and avenge the shame he has suffered at the hands of the Black Knight, now besieging the castle of the « orgoillose pucele» (v. 3485).

Again we have competing demands on Arthur, and it appears that he has again made the wrong decision, as he seems more intent on avenging his own shame than on discharging his feudal obligation to assist his vassal. Neither of his tasks is ill-advised or unusual in Arthurian fiction, but there is decidedly a question of priority. Indeed, his declining to offer immediate assistance to Talac appears more serious now than had been his neglect of the besieged lady who first asked his aid. In the earlier episode, it was acknowledged that the lady's castle, well fortified and filled with provisions, could hold out for an extended time without assistance. She was not in dire straits, and her entreaty to Arthur was based solely on the shame that would attach to him if he failed to assist her. But now, in the second of these paired sequences, Talac's castle is not well equipped, and without Arthur's assistance, his situation will quickly become desperate (v. 3434-39). No matter: faced with a pressing need to come to Talac's aid, Arthur chooses instead to undertake a different task, related again to his self-interest ${ }^{10}$.

${ }^{10}$ That we are meant to compare and contrast these two sequences cannot be in doubt. And there is even more. The first episode immediately followed Yder's disappointment and bitterness at being forgotten by Arthur. The second sequence is followed by another scene in which Yder considers himself mistreated and abandoned. In that one, Gauvain and Yvain, who are now Yder's friends, decide to join Talac but to leave Yder behind, because he was recently wounded, and they think him unable to ride and do battle. Yder, who considers himself entirely healed, is distraught and angry. Feeling more than a little self-pity, he laments his lot, considering himself dishonored and doubting the loyalty and friendship of the two other knights (v. 3521-43). And, as he had done when he thought himself mistreated by Arthur, he leaves court.

These sequences, though separated by over 3000 lines, are connected by symmetrical form, commonality of theme, and the reactions of both Arthur and Yder, the former appearing to value personal honor or fame over feudal obligations, the latter concerned with his status and easily offended when he thinks himself slighted. Yder laments, concerning Gauvain in particular, that «Es granz bosoins vait sanz moi» (v. 3527). He adds (in quite an impressive diatribe) :

«Deus, o trovera l'om mes foi?

Il n'en est mes point com mei semble;

Il e sire Ywain ensemble,

Compaignons estions ensemble,

Il e sire Ywains e joen ; 
So we are left with the question: who is the villain in this romance ? To my mind, it is not Arthur, or certainly not only Arthur - not even primarily Arthur. Unsurprisingly, on the other hand, Kei surely qualifies. At one point, he stabs Yder in the back - literally - and at another time he poisons him. He is resentful and hateful. Far from being the usually harmless (albeit irascible and sarcastic) gadfly of the court, Kei clearly represents here the nadir of chivalric behavior and character, lacking any redeeming social value. At the other end of the spectrum are Gauvain and Yvain. (Uncharacteristically for the French tradition, Gauvain appears to be an authentic hero in this work.)

Between these two poles - Kei at one end, Gauvain (and Yvain) at the other stand Yder and Arthur. Yder often appears to be something of a Perceval figure, remarkably talented for chivalry, but unknown and untried when the romance begins. On more than one occasion, it should be noted, he also demonstrates a prodigious talent for self-pity indicative of immaturity.

And then there is Arthur. As my comments have demonstrated, it would be both impossible and senseless to paint him as an admirable character. I would argue, however, that he often has benevolent intentions, as when he wishes to express his gratitude to Yder for saving him; but he is distracted and forgetful, and it occurs to him to thank Yder only after the latter has left court. In addition, his intense jealousy is unarguably a destructive force. In official matters, he appears disengaged and erratic, and he is strongly decisive only when he is doing the wrong thing : acting out of jealousy or inverting his priorities and postponing legitimate obligations.

His disengagement is perhaps most remarkable in regard to Kei. Traditionally Arthur had tolerated Kei's sarcasm and invective, and he generally limits himself to reprimanding the seneschal for his failings. In Yder, however, he does not do even that, remaining passive when Kei is at his most outrageous. Kei's two attempts to murder Yder do not elicit even a rebuke from the king ${ }^{11}$, and Kei's position at court is not threatened even when Gauvain argues to Arthur that the seneschal must be punished. We cannot of course know how the king would ultimately have responded

\author{
Itant avoie de mon boen, \\ Non de mon boen, mes de confort. \\ Mult one eu vers moi grant tort. \\ Ore en vont mi dui compaignon, \\ Ne me dient ou ne non; \\ Vis m'est que nostre compaignie \\ Que prise estoit par foi plevie \\ Define en vilanie parclose. \\ Ne me prisent guers de chose, \\ N'ont de ma compaignie cure » (v. 3528-42).
}

The narrator then explains that Gauvain, «out of loyal love» («od feel amor», v. 3548) wanted Yder to be able to rest and recover from his wound.

${ }^{11}$ As noted, even if we choose to assume that Arthur's jealousy led him to wish for Yder's death - and I do not think it goes quite so far - at other times Arthur is fond of the hero and delighted at his successes. We cannot therefore make the argument that Arthur tolerates Kei's treachery merely because Kei was carrying out the king's wishes. Instead, Arthur seems almost indifferent to what is occurring around him. 
to Gauvain's complaint, for just at that point, news comes that Yder is alive, and the incident is promptly and completely forgotten. Treacherous and cowardly assault on a knight from behind is apparently unobjectionable as long as the victim survives at least when the attacker is Kei and the king is Arthur. The episode clearly does not add any luster to Arthur's character, though it appears not to compromise his reputation with others. Surprisingly, even Gauvain seems largely to forget about Kei's crime, as if life at the court is separated out into discrete experiential units. These units are sometimes linked - sometimes not - by the continuity of narrative threads, but they often remain entirely unrelated to one another in terms of the characters' reactions and memories.

But it cannot be said that everything concerning the court is evil. At most, part of it is. The court contains the full range of human behaviors, from Kei's treachery and hatred to Gauvain's near perfection. The problem is precisely that the court, while not in itself evil, also does not function as a force for good. The romance and the court have no ideological core. Other romances, even as they dramatize Arthur's failures, generally maintain a sense of the Arthurian ideal, and that provides an anchor, a mooring for the text and the court. But in this text, the court has been cut conspicuously loose from its mooring in the ideal of Camelot and the Round Table. It has no anchor to stabilize it.

The court, I suggest, is not evil as much as it is simply adrift. It is a space within which events are often severed from their expected consequences. Of course, we can easily enough argue that Arthur is by no means what he should be or even what he is described as being. He is indecisive and irresolute, and he is tormented by jealousy and in serious need of lessons in anger management. As a result the court is largely without direction. All of that is patently obvious, but whereas it surely contradicts the description, quoted at the beginning, of Arthur as a great and inspiring monarch, a paragon of valor, wisdom, courtliness, and honor surpassing all others, it does not make either the king or the court unequivocally or irremediably evil.

An evil Arthur is by no means inconceivable, but I would argue that the Arthur of Yder is far more complex and intriguing than he would be as a simple villain - or perhaps even as a genuine hero. Primarily, he is inconsistent: his characteristics range from magnanimity and generosity to disengagement and distraction to jealousy and rage. (Indeed, this may well be the most complex Arthur to be found in French romance.) And since the court is a reflection of the king, his flaws have shaped (or perhaps misshapen) the court so that it is no longer an ideal, but just a place. It provides the sense of a center in little more than a geographical way; the knights (except for Gauvain, Yvain, and sometimes Yder) are not a brotherhood, but merely a loose collection of individuals, almost of strangers. In fact, apart from those I have mentioned, the author names only about fifteen knights of the Round Table, and fully a dozen are names that occur only in this romance. The experience, for anyone who knows the Arthurian tradition, is a shock of nonrecognition. There is not only a faithful and loving Guenevere - itself already something of a novelty - but a king who, although praised, is at very least erratic and clearly flawed. And he presides - more or less - over a Round Table whose members include such "illustrious» knights as Bedouer, Gastinel, Gasoudenc, Guhu, Buhout, and Buflout. Yet, if his court and many of his knights appear to lack 
distinction and consistency, I would still maintain that Arthur himself does not incarnate evil. He simply fails to be the standard-bearer and enforcer of good, and as a result, he is the leader of a decaying ideal : a rudderless Camelot that is no more than the locus of random, fragmented, and almost alien experience.

Norris J. Lacy

Pennsylvania State University 